\title{
INCOME TAX ASPECTS OF CRYPTOCURRENCIES - LEGAL AND YOUNG ECONOMISTS' VIEW IN THE CZECH REPUBLIC
}

\author{
Filip Hampl ${ }^{1}$
}

Received: November 22, 2019 / Revised: January 3, 2020 / Accepted: February 11, 2020

(C) Association of Economists and Managers of the Balkans, 2020

\begin{abstract}
Cryptocurrencies are used not only as a payment instrument but also as a speculative and investment instrument. In the context of their use, the question arises of how and whether they should be taxed. The aim of the paper is to analyse and to assess the taxation of income from the cryptocurrency operations from the perspective of a non-business natural person in compliance with the Act on Income Taxes in the Czech Republic, concurrently to find out the attitude of young future economists familiar with cryptocurrencies to this tax issue and to identify socioeconomic factors influencing their attitude. For this purpose, an online questionnaire survey was conducted among economists aged 19-35 years in May 2019. A total of 269 responses were obtained and evaluated using descriptive statistics and ordinal regression. While, according to the effective law, income from all cryptocurrency operations is to be taxed, the results show that most of the respondents (44.98\%) would tax the income depending on how cryptocurrencies are used.
\end{abstract}

Keywords: Personal Income Tax, Act on Income Taxes, Natural Person, Survey, Thing in a Legal Sense, Virtual Currencies

JEL Classification E64 $\cdot$ K40

This paper was presented at the Third International Scientific Conference on IT, Tourism, Economics, Management and Agriculture - ITEMA 2019 - October 24, Bratislava, Slovakia, www.itema-conference.com

Filip Hampl

filip.hampl@econ.muni.cz

1 Department of Finance of the Faculty of Economics and Administration, Masaryk University; Lipová 41a, 60200 Brno-Pisárky, Czech Republic 


\section{INTRODUCTION}

Cryptocurrencies represent modern digital assets without physical substance existing in the form of consensually confirmed records in distributed, oftentimes publicly accessible databases called blockchains (Hern, 2018). Cryptocurrency transactions are enabled by computer cryptocurrency networks using asymmetric cryptography algorithms to secure and verify realized transactions and control generation of new cryptocurrency units (Delmolino et al., 2016). Cryptocurrencies grabbed general public attention in the course of the year 2017 in connection with the sharp rise in the price of cryptocurrency Bitcoin. For instance, the number of cryptocurrency exchange Coinbase users increased from 0.4 million in January 2017 to 11.1 million in January 2018 (Szmigiera, 2019). Since that time, many people have decided to purchase cryptocurrencies in order to utilize their potential to generate capital income. These gains are feasible due to relatively high volatility of cryptocurrencies (which was discussed by e.g. Baur and Dimpfl, 2018 or Miglietti et al., 2019). Therefore, although cryptocurrencies were intended primarily to serve as an electronic tool to make payments directly between any two willing parties without the need for financial institutions (Nakamoto, 2008), they have become rather investment or speculative assets for many users (Blau, 2017; Brauneis and Mestel, 2019). Several studies (e.g. Corbet et al., 2018) have stated that cryptocurrencies can be used as an asset for investment portfolio diversification.

For cryptocurrency users, the question arises whether income generated from cryptocurrency operations like payments, transfers etc. is subject to personal income tax. Although cryptocurrency networks do not have a central authority to oversee realised transactions (Hern, 2018), this does not mean that the transactions and their senders are anonymous. All confirmed transactions are traceable in the form of pseudo-anonymous records in publicly accessible blockchains which thus serve as the public ledgers of cryptocurrencies (Berentsen and Schär, 2018). Several studies (e.g. Kumar et al., 2017 or Khalikov and Levi, 2018) found out that the identity and the profile of a user can be revealed and cryptocurrency transactions can be traced by using combination of data from blockchain with external computer data - it follows that tax administrators may be capable to identify taxpayers and their taxable income. Thus, the first aim of the paper is to analyse and to assess the taxation of income from cryptocurrency operations from the perspective of a non-business natural person in the Czech Republic.

In addition, the question can be discussed whether income from cryptocurrency operations should be subject to personal income tax. As mentioned above, cryptocurrencies can be considered on the one hand a payment instrument like "legal" tender (according to Sabah (2019), the global number of retailers accepting cryptocurrencies is constantly increasing) and on the other hand a speculative or an investment instrument. The second aim of the paper is to find out the attitude of young future economists familiar with cryptocurrencies to the issue of their personal income taxation and to identify factors influencing the attitude. Recent surveys (e.g. Leinz, 2018; Willims, 2019 or Mrazkova, 2018) showed that young people are familiar with cryptocurrencies and purchase them more than older people. Therefore, they deal with taxation of income from cryptocurrency operations more often.

\section{LEGAL VIEW ON CRYPTOCURRENCY TAXATION IN THE CZECH REPUBLIC}

Taxation of income from cryptocurrency operations is not specifically regulated in the Czech Act on Income Taxes (1992), therefore general rules need to be applied. For the purposes of taxation, it is necessary to determine the legal factual nature of cryptocurrencies. Pursuant to the Czech law, 
cryptocurrencies are not considered legal tender (Act on the Czech National Bank, 1993), funds (Act on Payments, 2017), investment instruments (Act on Capital Market Business, 2004) nor securities (Civil Code, 2012). They can be only subsumed into the most general legal institute of a thing in a legal sense which, pursuant to the Civil Code (2012, section 489), means everything that is different from a person and serves the needs of people. Legally, cryptocurrencies are construed as any other incorporeal goods, i.e. cryptocurrency payments for goods or services and mutual exchanges of various cryptocurrencies are considered barters of one thing for another thing, and exchanges of cryptocurrencies for legal tender are considered cryptocurrency sales.

Income from sales or barters of cryptocurrencies is subject to the Czech personal income tax. In fact, in accordance with the Act on Income Taxes (1992, section. 3), not only monetary but also non-monetary income generated through barter is subject to tax. However, cryptocurrency possession itself is tax neutral (Beer, 2018) - taxable income does not arise until the cryptocurrency is sold or bartered, even if the market value of the cryptocurrency increases. Due to the legal nature of cryptocurrencies, non-business persons are not allowed to exempt income from cryptocurrencies operations (barters/sales). Cryptocurrencies are not securities, therefore income from their barter or sale cannot be exempted if the 3-year time test is met, or if taxable income does not exceed 100,000 CZK (approx. 3,910 EUR) for the taxation period. Concurrently, given the fact that they are not legal tender, income cannot be considered a tax-exempted exchange gain. (Act on Income Taxes, 1992, sections 3-4) Income from cryptocurrency operations are not considered occasional, thus no tax-exemption up to 30,000 CZK (approx. 1,170 EUR) on the grounds of occasionality is allowed (Act on Income Taxes, 1992, section 10 subsection 3).

Non-business income from cryptocurrency operations is treated like any other income generated from own property management (Trnkova Kocourkova, 2018; Vodicka, 2018). The tax base from cryptocurrency operations is calculated as taxable income less tax-deductible expense. Only the acquisition price and transaction fees associated with the cryptocurrency sale/barter may be recognised as a tax-deductible expense. Gains and losses on individual cryptocurrency transactions are offset but a total loss is disregarded. (Act on Income Taxes, 1992, section 10 sections 4-5). To calculate the amount of expense, accounting methods for valuing inventories of the same kind, i.e. FIFO ("first-in, first-out") or weighted arithmetic average, can be used (Act on Accounting, 1991, section 25). The tax base calculated from cryptocurrency operations is included in the taxpayer's general tax base from all kinds of income and subject to the $15 \%$ tax rate.

The problem of the current Czech taxation method consists in the need to keep a record of each cryptocurrency transaction, even if its value is low level. It means taxpayers are obliged to record each barter of cryptocurrencies for goods and services (each cryptocurrency retail payment), each barter of a cryptocurrency for another cryptocurrency and each cryptocurrency sale for legal tender. For every single transaction, taxable income, which arises if there is a value increase between the cryptocurrency purchase and its sale/barter, needs to be de jure determined. To sum up, the Czech taxation method can be considered inconsistent with taxing principles of ease of compliance, minimizing of compliance costs and tax efficiency (Mooij and Keen, 2014).

The Case Study 1 illustrates the complicatedness of the income tax base calculation from the perspective of a non-business natural person realising cryptocurrency operations. 
Case Study 1. Calculation of non-business person tax base from cryptocurrency operations

A non-business natural person purchased on the cryptocurrency exchange 10 units of cryptocurrency Litecoin (LTC) for 60 EUR/LTC. These units were used to the three transactions listed below. A transaction fee of 0.01 LTC was associated with each transaction.

\section{Transaction no. 1:}

Barter of merchandise valued 15 EUR for 0.25 LTC, exchange rate 60 EUR/LTC.

\section{Transaction no. 2:}

Barter of the same merchandise valued 15 EUR for 0.20 LTC, exchange rate 75 EUR/LTC:

\section{Transaction no. 3:}

Sale of 0.50 LTC for legal tender EUR, exchange rate 75 EUR/LTC.

Table 1 shows the calculation of the tax base from the transactions mentioned above. Taxable income is both monetary (transaction no. 3) and non-monetary (transactions no. 1 and 2 in value of bartered merchandise). Litecoin acquisition price and transaction fees represent tax-deductible expenses (valued at the purchase exchange rate).

Table 1. Calculation of the tax base from the cryptocurrency transactions Source: author's own calculations

\begin{tabular}{l}
\begin{tabular}{|l|c|c|c|c|c|c|}
\hline Trans. & $\begin{array}{c}\text { Units in } \\
\text { transaction }\end{array}$ & $\begin{array}{c}\text { Transaction } \\
\text { fee }\end{array}$ & Exchange rate & Taxable income & $\begin{array}{c}\text { Tax-deductible } \\
\text { expense }\end{array}$ & $\begin{array}{c}\text { Amount added } \\
\text { to the tax base }\end{array}$ \\
\hline Purchase & $10.00 \mathrm{LTC}$ & -- & $60 \mathrm{EUR} / \mathrm{LTC}$ & -- & -- & -- \\
\hline no. 1 & $0.25 \mathrm{LTC}$ & $0.01 \mathrm{LTC}$ & $60 \mathrm{EUR} / \mathrm{LTC}$ & $15.00 \mathrm{EUR}$ & $15.60 \mathrm{EUR}$ & $-0.60 \mathrm{EUR}$ \\
\hline no. 2 & $0.20 \mathrm{LTC}$ & $0.01 \mathrm{LTC}$ & $75 \mathrm{EUR} / \mathrm{LTC}$ & $15.00 \mathrm{EUR}$ & $12.60 \mathrm{EUR}$ & $+2.40 \mathrm{EUR}$ \\
\hline no. 3 & $0.50 \mathrm{LTC}$ & $0.01 \mathrm{LTC}$ & $75 \mathrm{EUR} / \mathrm{LTC}$ & $37.50 \mathrm{EUR}$ & $30.60 \mathrm{EUR}$ & $+6.90 \mathrm{EUR}$ \\
\hline Total tax base (taxable income - deductible expenses): & $\mathbf{6 7 . 5 0 \mathrm { EUR }}$ & $\mathbf{5 8 . 8 0} \mathrm{EUR}$ & $\mathbf{8 . 7 0 ~ E U R ~}$ \\
\hline
\end{tabular} \\
Total tax base taxed at $15 \%$ is $8.70 \mathrm{EUR}$. \\
\hline
\end{tabular}

Source: author's own processing

\subsection{Comparison with Neighbour States}

In the neighbour states, i.e. the Slovak Republic, the Republic of Poland and the Federal Republic of Germany, income of non-business natural persons from cryptocurrency operations is taxed in the same method like in the Czech Republic. In all mentioned neighbour countries, the tax base is also determined as the difference between the income from cryptocurrency operations and cryptocurrency acquisition price plus transaction fees (Slovak Act on Income Taxes, 2003; Polish Act on Income Taxes, 1991; German Act on Income Taxes, 1934). However, in the Republic of Poland, income from barters of a cryptocurrency for another cryptocurrency is not subject to personal income tax, i.e. trading with cryptocurrencies on cryptocurrency exchanges is not taxable (Polish Act on Income Taxes, 1991, article 17 subsection 1f; Ciszewski, 2018). Besides, in the Federal Republic of Germany, cryptocurrencies in possession of non-business natural persons are considered private money and operations with these cryptocurrencies are considered private business transactions. Income from such transactions is tax-exempt if the cryptocurrencies are held for at least one year (time test), or if 
the tax base from all private business transactions does not exceed 600 EUR for a taxation period (Zitzmann, 2017). These differences in the Republic of Poland and the Federal Republic of Germany make tax administration there easier and reduce costs of taxpayers to comply the tax law.

\section{YOUNG ECONOMISTS'S VIEW}

Cryptocurrencies are relatively new financial assets which can serve as payment, speculative or investment instrument. Therefore, the question arises whether cryptocurrencies should be subject to personal income tax or more precisely whether they should be taxed regard to their use. The answer to this question and the attitude to taxation of income from cryptocurrency operations were investigated among young future economists aged 19-35 years.

\subsection{Methodology and Data}

In order to find out the attitude of young future economists on cryptocurrency taxation, an online questionnaire survey among students of the Faculty of Economics and Administration of Masaryk University located in Brno (Czech Republic) was conducted in May 2019. Young people-students (i.e. the age group 19-35 years) were chosen for the research because they are more interested in new technology innovations, are more willing to try them and as students of economics, they may become tax policymakers in the future. Recent studies confirmed that young people are familiar with cryptocurrencies. A survey conducted by an online Bitcoin marketplace Paxful among young people aged 18-42 years in August 2019 showed that $98.4 \%$ of respondents were familiar with Bitcoin, 77.4\% with Ethereum, 71.6\% with Litecoin and 47.6\% with Ripple (Willims, 2019). In addition, according to a joint SurveyMonkey and Global Blockchain Business Council poll, $58 \%$ of cryptocurrency investors are young people aged 18-34 years (Leinz, 2018).

A total of 2,677 students of the Faculty of Economics and Administration were contacted via e-mail. A total of 269 responses were obtained, i.e. response rate was 10.05\%. All respondents $(100 \%)$ stated that they are familiar with cryptocurrencies like Bitcoin, Ethereum or Litecoin. Table 2 shows the profile of the survey participants. The questionnaire contained close-ended questions and one open-ended question and was created in LimeSurvey software.

Table 2. Characteristics of survey participants $(n=269)$

Source: author's own processing

\begin{tabular}{|c|c|c|}
\hline Characteristics & Number of responses & $\begin{array}{c}\text { Number of responses } \\
\text { in } \%\end{array}$ \\
\hline \multicolumn{3}{|l|}{ Gender: } \\
\hline Male & 147 & $54.65 \%$ \\
\hline Female & 122 & $45.35 \%$ \\
\hline \multicolumn{3}{|l|}{ Education: } \\
\hline Student of bachelor study programme & 141 & $52.42 \%$ \\
\hline Student of the follow-up master's study programme & 116 & $43.12 \%$ \\
\hline Student of the doctoral study programme & 12 & $4.46 \%$ \\
\hline \multicolumn{3}{|l|}{ Nationality: } \\
\hline A resident of the Czech Republic & 189 & $70.26 \%$ \\
\hline A resident of the Slovak Republic & 80 & $29.74 \%$ \\
\hline Resident of other countries & 0 & $0.00 \%$ \\
\hline
\end{tabular}


The close-ended questions were used in the survey to collect socioeconomic data and to find out whether income from cryptocurrency operations should be in respondents view taxed by personal income tax. The open-ended question was intended to provide the respondents with the option to explain their attitude and to propose changes to the current method of taxation. Obtained responses were evaluated in case of close-ended questions using descriptive statistics and ordinal regression. The open-ended question was evaluated qualitatively.

Ordinal regression estimated by maximum likelihood method was employed due to the dataset structure to identify statistically significant socioeconomic factors influencing respondents' attitude to the taxation. The following socioeconomic factors were employed as independent variables: age, gender, nationality (Czech or Slovak), education, size_town (the size of the town of respondents' origin), study_stay, practical_train and job (the last three variables were employed to express respondents' working/foreign study experience). All assumptions were met.

MS Excel was used to descriptive evaluation of responses and R Programming Language was used to perform statistical tests.

\subsection{Results and Discussion}

Table 3 presents respondents' answers to the question "Do you think that income from cryptocurrency non-business operations should be taxed by personal income tax?" Therefore, the results show their attitude to the cryptocurrency income taxation from the perspective of non-business natural persons.

Table 3. Respondents' attitude to the cryptocurrency income taxation (number of responses in the absolute and relative expression)

Source: author's own calculations based on the results of the survey

\begin{tabular}{|c|c|c|c|c|c|c|c|c|}
\hline \multicolumn{9}{|c|}{$\begin{array}{l}\text { Do you think that income from cryptocurrency non-business operations } \\
\text { should be taxed by personal income tax? }\end{array}$} \\
\hline & \multicolumn{2}{|c|}{ YES } & \multicolumn{2}{|c|}{\begin{tabular}{|c|}
$\begin{array}{c}\text { YES, but depends } \\
\text { on the use }\end{array}$ \\
\end{tabular}} & \multicolumn{2}{|c|}{ NO } & \multicolumn{2}{|c|}{ NO OPINION } \\
\hline Total $(n=269)$ & 35 & $13.01 \%$ & 121 & $44.98 \%$ & 85 & $31.60 \%$ & 28 & $10.41 \%$ \\
\hline \multicolumn{9}{|l|}{ Responses by gender: } \\
\hline Male $(n=147)$ & 23 & $15.65 \%$ & 67 & $45.58 \%$ & 40 & $27.21 \%$ & 17 & $11.56 \%$ \\
\hline Female $(n=122)$ & 12 & $9.83 \%$ & 54 & $44.26 \%$ & 45 & $36.89 \%$ & 11 & $9.02 \%$ \\
\hline \multicolumn{9}{|l|}{ Responses by education: } \\
\hline $\begin{array}{l}\text { Student of bachelor pro- } \\
\text { gramme }(\mathrm{n}=141)\end{array}$ & 18 & $12.77 \%$ & 60 & $42.55 \%$ & 45 & $31.91 \%$ & 18 & $12.77 \%$ \\
\hline $\begin{array}{l}\text { Student of the follow-up } \\
\text { master's programme ( } \\
=116 \text { ) }\end{array}$ & 12 & $10.34 \%$ & 57 & $49.14 \%$ & 37 & $31.90 \%$ & 10 & $8.62 \%$ \\
\hline $\begin{array}{l}\text { Student of doctoral pro- } \\
\text { gramme }(\mathrm{n}=12)\end{array}$ & 5 & $41.67 \%$ & 4 & $33.33 \%$ & 3 & $25.00 \%$ & 0 & $0.00 \%$ \\
\hline \multicolumn{9}{|l|}{ Responses by nationality: } \\
\hline $\begin{array}{l}\text { Resident of the Czech } \\
\text { Republic }(\mathrm{n}=189)\end{array}$ & 26 & $13.76 \%$ & 78 & $41.27 \%$ & 63 & $33.33 \%$ & 22 & $11.64 \%$ \\
\hline $\begin{array}{l}\text { Resident of the Slovak } \\
\text { Republic }(\mathrm{n}=80)\end{array}$ & 9 & $11.25 \%$ & 43 & $53.75 \%$ & 22 & $27.50 \%$ & 6 & $7.50 \%$ \\
\hline
\end{tabular}


The obtained results show most young future economists (57.99\%) believe that income from cryptocurrency non-business operations should be taxed by personal income tax. But only 13.01\% of respondents agree with the current method of cryptocurrency income taxation in the Czech Republic - they would like to continue to tax all income from all cryptocurrency barters or sales.

The prevailing number of respondents (44.98\%) would tax income from cryptocurrency operations depending on cryptocurrency purpose of use. Students suggested that income from cryptocurrencies should have been treated like securities. It means it would be possible to exempt income generated by a non-business person in case that the 3 -year time test is met, or income does not exceed 100,000 CZK (approx. 3,910 EUR) for a taxation period. Therefore, short-term speculative cryptocurrency trades would be taxed but long-term investments not. If cryptocurrencies are used as payments for goods or services, non-monetary income from these transactions should not be according to respondents taxed at all, i.e. it should be fully tax-exempted or not subject to personal income tax. This attitude is in compliance with the tax principle of tax administration simplicity.

On the other hand, $31.60 \%$ of respondents do not consider cryptocurrencies to be subject to personal income tax. Based on their provided explanation, it can be concluded that they regard cryptocurrencies as something like "legal" tender (traditional currency) which is not taxed in case of non-business natural persons. Some of students do not want to tax income from cryptocurrency operations because they believe in unregulated, distributed and state-independent nature of cryptocurrencies. In their opinion, potential taxation would violate one of the main ideas of cryptocurrencies - the absence of state intervention.

The results show that larger proportion of females (36.89\%) than males $(27.21 \%)$ holds the view that income from cryptocurrency operations should not be taxed. With respect to education, students of doctoral study programme are much more supportive of taxation of income from all cryptocurrency operations in comparison with students of bachelor and the follow-up master's study programmes.

However, age, education and other socioeconomic factors are not statistically significant (t-test values are lower than the value of 2). Table 4 shows the results of ordinal regression and statistical significance of socioeconomic factors influencing the young economists' attitude to the taxation of income from cryptocurrency operations.

Table 4. Results of ordinal regression

Source: author's own calculations

\begin{tabular}{|l|c|c|c|c|}
\hline Variable & Value & Standard error & t-value & Significance \\
\hline gender & -0.2631 & 0.2556 & -1.0293 & $\mathrm{~ns}$ \\
\hline age & -0.0612 & 0.0450 & -1.3584 & $\mathrm{~ns}$ \\
\hline nationality & 0.4096 & 0.2818 & 1.4536 & $\mathrm{~ns}$ \\
\hline size_town & 0.0054 & 0.0877 & 0.0616 & $\mathrm{~ns}$ \\
\hline education & 0.2757 & 0.2561 & 1.0764 & $\mathrm{~ns}$ \\
\hline study_stay & 0.2023 & 0.3322 & 0.6090 & $\mathrm{~ns}$ \\
\hline practical_training & 0.3662 & 0.5419 & 0.6758 & $\mathrm{~ns}$ \\
\hline job & 0.4041 & 0.3820 & 1.0578 & $\mathrm{~ns}$ \\
\hline intercept $0 \mid 1$ & -1.2119 & 0.9202 & -1.3170 & $\mathrm{~ns}$ \\
\hline intercept $1 \mid 2$ & -0.5988 & 0.9175 & -0.6527 & $\mathrm{~ns}$ \\
\hline
\end{tabular}

Note: "ns" indicates no statistical significance. 
Recent studies tend to think that income from cryptocurrency operations should be subject to income tax (e.g. Akins et al. 2015; Xu, 2019 or Kjærsgaard and Arfwidsson, 2019). Pursuant to the current Czech tax legislation, income from all cryptocurrency operations has to be taxed. On the contrary, the conducted survey among young future economists showed that most of the respondents would tax income from cryptocurrency operations based on whether the cryptocurrency is used as payment, investment or speculative asset. Therefore, Czech legislators should make several changes to the current Act on Income Taxes (1992). They should extend the provisions relating to securities in order to be applicable on cryptocurrencies as well. Concurrently, a new provision about the tax treatment of cryptocurrency payments for goods and services should be added. Income for these transactions should not be subject to personal income tax or should be fully tax-exempt. Due to the proposed changes, cryptocurrencies used as a payment instrument would be treated like "legal" tender. Speculations with cryptocurrencies (exceeding 100,000 CZK for a taxation period) would be still taxable. Long-term cryptocurrency investments would be tax-exempt. This taxation method would respect the different options of using cryptocurrencies and would not put the cryptocurrencies at a disadvantage compared to other assets (i.e. legal tender and securities).

\section{FUTURE RESEARCH DIRECTIONS}

This paper analysed and assessed the taxation method of income from cryptocurrency operations in the Czech Republic and found out the attitude of young future economists to this tax issue. Future studies could extend the research by adding a comparison of cryptocurrency tax treatment in other European and Non-European countries and extend the data sample by natural persons aged 36 and older. Besides, future studies could examine factors influencing the attitude of natural persons to cryptocurrency taxation in more detail. Papers taking into account the attitude of legal persons to the taxation of cryptocurrency income would also be of importance.

\section{CONCLUSION}

The paper deals with the taxation of income from cryptocurrency operations (barters of cryptocurrencies for goods or services, barters of a cryptocurrency for another cryptocurrency and sales of cryptocurrencies for legal tender) from the perspective of non-business natural persons in compliance with the Czech Act on Income Taxes. Pursuant to this Act, all monetary and non-monetary income generated even through barter from all cryptocurrency operations regardless its amount is subject to personal income tax. No tax-exemption is possible due to legal nature of cryptocurrencies. Therefore, taxpayers are obliged to record each cryptocurrency transaction which may be demanding and costly for them. Current taxation method of cryptocurrency income violates the tax principles of ease of tax compliance, minimizing compliance costs and thereby tax efficiency. Due to the complicatedness of the taxation method, taxpayers may not tax all their cryptocurrency income properly.

Regard to current legal tax treatment, the paper found out the attitude of young future economists aged 19-35 years to the taxation of income from cryptocurrency operations and their suggestions for taxation changes. From a total of 269 respondents, 13.01\% would tax income from cryptocurrency operations just like the current Czech Act on Income Taxes, 44.98\% would tax income depending on how cryptocurrencies are used and $31.60 \%$ would not tax income at all. Socioeconomic factors do not have a statistically significant influence on the respondent's attitude. Based on the prevailing attitude, cryptocurrencies used as a speculative and investment instruments should be tax-treated like securities. It means the tax-exemption of income generated by a non-business person would be possible if the 3 -year time test is met, or income does not exceed 100,000 CZK 
(approx. 3,910 EUR). Cryptocurrencies used as a payment instrument for goods or services should be considered "legal" tender. Income from these transactions should be fully tax-exempt, or not subject to personal income tax at all.

\section{ACKNOWLEDGEMENT}

This contribution was created with the support of Masaryk University within the project of the specific research MUNI/A/1029/2018 "Financial Reporting and Tax Aspects of Cryptocurrencies".

\section{REFERENCES}

Act no. 256/2004 Coll., on Capital Market Business, as amended (2004, last amendment 2019). Retrieved November 18, 2019, from ASPI (legal information system provided by Wolters Kluwer).

Act no. 370/2017 Coll., on Payments, as amended (2017, last amendment 2019). Retrieved November 18, 2019, from ASPI (legal information system provided by Wolters Kluwer).

Act no. 563/1991 Coll., on Accounting, as amended (1991, last amendment 2018). Retrieved November 18, 2019, from ASPI (legal information system provided by Wolters Kluwer).

Beer, D. (2018). Zdanění virtuálních měn (Taxation of Virtual Currencies). Retrieved November 22, 2019, from https://www.dauc.cz/dokument/?modul=li\&cislo=252023.

Act no. 586/1992 Coll., on Income Taxes, as amended (1992, last amendment 2019). Retrieved November 18, 2019, from ASPI (legal information system provided by Wolters Kluwer).

Act no. 6/1993 Coll., on the Czech National Bank, as amended (1993, last amendment 2019). Retrieved November 15, 2019, from ASPI (legal information system provided by Wolters Kluwer).

Act no. 89/2012 Coll., Civil Code, as amended (2012, last amendment 2018). Retrieved November 18, 2019, from ASPI (legal information system provided by Wolters Kluwer).

Akins, B. W., Chapman, J. L., \& Gordon, J. M. (2015). A Whole New World: Income Tax Considerations of the Bitcoin Economy. Pittsburgh Tax Review, 12(1), 24-56. doi: 10.5195/taxreview.2014.32

Baur, D. G., \& Dimpfl, T. (2018). Asymmetric volatility in cryptocurrencies. Economics Letters, 173, 148-151. https://doi.org/10.1016/j.econlet.2018.10.008

Berentsen, A., \& Schar, F. (2018). A Short Introduction to the World of Cryptocurrencies. Review, 100(1), 1-19. Retrieved from https://doi.org/10.20955/r.2018.1-16

Blau, B. M. (2017). Price dynamics and speculative trading in bitcoin. Research in International Business and Finance, 41, 493-499. Retrieved from https://doi.org/10.1016/j.ribaf.2017.05.010

Brauneis, A., \& Mestel, R. (2019). Cryptocurrency-portfolios in a mean-variance framework. Finance Research Letters, 28, 259-264. Retrieved from https://doi.org/10.1016/j.frl.2018.05.008

Ciszewski, P. (2018). Rozliczanie kryptowalut na nowych zasadach. Retrieved November 22, 2019, from https://www.infakt.pl/blog-ksiegowy/rozliczanie-kryptowalut-na-nowych-zasadach/.

Corbet, S., Meegan, A., Larkin, C., Lucey, B., \& Yarovaya, L. (2018). Exploring the dynamic relationships between cryptocurrencies and other financial assets. Economics Letters, 165, 28-34. Retrieved from https://doi.org/10.1016/j.econlet.2018.01.004

Delmolino, K., Arnett, M., Kosba, A., Miller, A., \& Shi, E. (2016). Step by Step Towards Creating a Safe Smart Contract: Lessons and Insights from a Cryptocurrency Lab. Financial Cryptography and Data Security Lecture Notes in Computer Science, 79-94. https://doi.org/10.1007/978-3662-53357-4_6

German Act on Income Taxes (Einkommensteuergesetz), as amended (1934, last amendment 2019). Retrieved November 22, 2019, from https://www.gesetze-im-internet.de/estg/.

Hern, A. (2018). Bitcoin and cryptocurrencies - what digital money really means for our future. Retrieved November 20, 2019, from https://www.theguardian.com/technology/2018/jan/29/cryptocurrencies-bitcoin-blockchain-what-they-really-mean-for-our-future. 
Khalilov, M. C. K., \& Levi, A. (2018). A Survey on Anonymity and Privacy in Bitcoin-Like Digital Cash Systems. IEEE Communications Surveys \& Tutorials, 20(3), 2543-2585. doi: 10.1109/ comst.2018.2818623

Kjærsgaard, L. F., \& Arfwidsson, A. (2019). Taxation of Cryptocurrencies from the Danish and Swedish Perspectives. Intertax, 47(6/7), 620-634. Retrieved from http://www.kluwerlawonline.com/ abstract.php?id=TAXI2019061.

Kumar, A., Fischer, C., Tople, S., \& Saxena, P. (2017). A Traceability Analysis of Monero's Blockchain. Computer Security - ESORICS 2017 Lecture Notes in Computer Science, 153-173. Retrieved from https://doi.org/10.1007/978-3-319-66399-9_9

Leinz, K. (2018). A Look at Who Owns Bitcoin (Young Men), and Why (Lack of Trust). Retrieved November 22, 2019, from https://www.bloomberg.com/news/articles/2018-01-24/a-look-at-whoowns-bitcoin-young-men-and-why-lack-of-trust.

Miglietti, C., Kubosova, Z., \& Skulanova, N. (2019). Bitcoin, Litecoin, and the Euro: an annualized volatility analysis. Studies in Economics and Finance, ahead-of-print (ahead-of-print). Retrieved from https://doi.org/10.1108/SEF-02-2019-0050

Mooij, R. de, \& Keen, M. (2014). Taxing Principles. Retrieved November 22, 2019, from https://www. imf.org/external/pubs/ft/fandd/2014/12/basics.htm.

Mrazkova, S. (2018, October 26). Kryptoměny, fondy či vzdělání. Mladí Češi jdou do rizikových investic (Cryptocurrencies, funds or education. Czech Young People Invest in Risky Instruments). Retrieved November 22, 2019, from https://perpetuum.cz/2018/06/kryptomeny-fondy-ci-vzdelani-mladi-cesi-jdou-do-rizikovych-investic/.

Nakamoto, S. (2008). A Peer-to-Peer Electronic Cash System. Retrieved November 22, 2019, from https://bitcoin.org/en/bitcoin-paper

Polish Act on Income Taxes, as amended (1991, last amendment 2019). Retrieved November 22, 2019, from http://prawo.sejm.gov.pl/isap.nsf/download.xsp/WDU19910800350/U/D19910350Lj.pdf.

Sabah, N. (2019). Cryptocurrency accepting venues, investor attention, and volatility. Finance Research Letters, 101339. Retrieved from https://doi.org/10.1016/j.frl.2019.101339

Slovak Act no. 595/2003 Coll., on Income Taxes, as amended (2003, last amendment 2019). Retrieved November 18, 2019, from ASPI (legal information system provided by Wolters Kluwer).

Szmigiera, M. (2019). Number of Coinbase users monthly 2017-2018. Retrieved November 22, 2019, from https://www.statista.com/statistics/803531/number-of-coinbase-users/.

Trnkova Kocourkova, H. (2018). Daně a kryptoměny (Taxes and Cryptocurrencies). Bulletin Komory certifikovaných účetních, 2018(2), 22-23.

Vodicka, M. (2018). Kryptoměna, kryptoaktivum a kryptověc (Cryptocurrency, Cryptoasset and Cryptothing). Retrieved November 22, 2019, from https:/www.dauc.cz/dokument/?modul=li\&cislo $=260629$.

Willms, J. (2019). Research: Young Adults Cryptocurrency Revolution „, Bitcoin Magazine. Retrieved November 22, 2019, from https://bitcoinmagazine.com/articles/new-research-shows-howyoung-adults-drive-the-cryptocurrency-revolution.

$\mathrm{Xu}$, D. (2018). Free Money, but Not Tax-Free: A Proposal for the Tax Treatment of Cryptocurrency Hard Forks. Fordham L. Rev, (87), 2693. Retrieved from https://heinonline.org/HOL/LandingPage?handle=hein.journals/flr87\&div $=95 \&$ id $=\&$ page $=$.

Zitzmann, F. (2017). Steuerliche Behandlung der Kryptowährungen. Retrieved November 22, 2019, from https:/www.haufe.de/compliance/management-praxis/steuerliche-behandlung-der-kryptowaehrungen_230130_431018.html. 